\title{
THE VERY MODEL OF A MODERN DOCTOR GENERAL
}

I am the very model of a modern Doctor General, With regulation politic, that borders on obsessional. There's no limit on what l'll do, nor any lack of willing To prostrate myself, and principles too, for an extra shilling; And if a fellow sprains a wrist, or suffers minor injury, Then I will feel professionally obliged to do the work for free; And on a morning Saturday, well, I think it's rather splendid, To sit in clinic by myself, in a spot of hours extended.

I am told by the health department, that QOF rewards are handsome. I love to tick little boxes, though I'm being held to ransom: With regulation politic, that borders on obsessional, I am the very model of a modern Doctor General.

And I obey every nuance, of the very latest guideline, I would never dare to question the expert wisdom they enshrine, If I'm instructed to prescribe, then I would not be so chary, To let such old-fashioned concepts rule as primum non nocere; By fancy graphics and slick commercial slogans I can be wowed, By PCT 'advisors' overbearing I am eas'ly cowed; I used to be the epitome of a very bitter cynic, But now am a believer, in the the power of polyclinic.

I am happy for my records, to be uploaded to the Spine, Though it is a failing backbone, it's a far stronger one than mine: With regulation politic, that borders on obsessional, I am the very model of a modern Doctor General.

There's nothing more that thrills my heart, than to Choose and Book it, I have to give the patients Choice, though the whole idea is unfit, And I address referral letters 'Dear Consultant Generic'

Even though I know who is just the chap to do the very trick.

I am driven by a sense of inexorable vocation, And I'll happily revalidate with much self-flagellation, My patients rate me highly, but I love to feel inferior. I've been appraised so many degrees, I see up my own posterior.

Our lords and masters (but not patients!) are sure that l'm a Shipman, I wish instead of general practice, that I had been a hip man: With regulation politic, that borders on obsessional, I am the very model of a modern Doctor General.

\section{Dan Edgcumbe}

DOI: $10.3399 /$ bjgp09X453369 